\title{
8 Physiognomic roots in the rhetoric of Cicero and Quintilian: The application and transformation of traditional physiognomics
}

Physiognomics is an art, a technique, a previous stage of knowledge, which has its roots in very remote times and cultures. According to physiognomics, an individual's inner nature could be revealed and judged, and even his future forecast, on the basis of the analysis of his physical features. It relies on the idea that the visible is a faithful reflection of the invisible, and that the inner nature and the outer appearance are closely linked together, as soul with body. Physiognomics focuses on fixed, permanent, static signs, whereas pathognomics, etymologically and basically a 'gnomê' of 'pathos', namely the study and knowledge of the changing human passions and their effects, relies on ephemeral, mutable and time-varying signs. The history of physiognomics and pathognomics are connected and intertwined: they are not completely separated before Lavater's work in the 19th century of our era. In ancient times, elements of pathognomics are mostly related to physiognomic developments, as shown by the physiognomic roots of Roman rhetoric. To some extent, Graeco-Roman rhetoric supplies a focal point for oversight regarding the application and transformation of traditional physiognomics, which has been little studied from this point of view.

In this chapter, I intend to shed light on the process of incorporation of both physiognomic and pathognomic elements in rhetoric. Their connections are particularly intense and fertile in Cicero's and Quintilian's rhetorical writings, which are the inheritors of three main traditions: physiognomics, rhetoric, and the problem of passions in line with Aristotle's work. Drawing on a historical and philosophical approach, I will highlight the long-term process and the main evolutions that lead to Roman rhetoric, with an emphasis on continuities rather than disruptions. I will focus especially on chronological and logical connections. Thus, I will deal with the body of knowledge of ancient traditional physiognomics broadly, including the writings before and contemporary with Pseudo-Aristotle's Physiognomonica, and on the other hand the main references of rhetoric until Cicero and Quintilian so as to provide key interpretations of their rhetorical works. Cicero's rhetorical work consists of the following dialogues: De inventione, De oratore, Brutus, Orator. Quintilian's rhetorical theory is primarily found in his Institutio oratoria, the most extensive treatise that survives from antiquity following Cicero. Moreover, the application and transformation of traditional physiognomics into rhetoric goes hand in hand with a debate on the status of signs, the passions, and body language. Within this setting, 'actio', namely the delivery of speech, is a key element to reveal the difference and proximity between 
physiognomics and rhetoric. First, I shall provide an overview of Graeco-Roman rhetoric's historical legacies up to the time of Cicero and Quintilian. Then, I shall focus on the roots and focal points of physiognomics and rhetoric. Finally, I shall outline their junction and renewal, conveyed by the issue of the 'eloquent body' that is conveyed in the 'actio'.

\section{An overview of Graeco-Roman rhetoric: Historical legacies in Cicero and Quintilian}

The word 'rhêtorikê' is first established in texts from 390 B.C., namely in Alcidamas's Against the Sophists and in Plato's Gorgias. ${ }^{1}$ In antiquity, there is neither a consensus on the definition of rhetoric nor on its means and goals. In the De Inventione, Cicero conceives rhetoric on the one hand as a legitimate means of government, and on the other hand he suggests that it feeds stormy debates and arouses personal anger in trials. ${ }^{2}$ His definition of rhetoric (ars dicendi) is quite different, depending on the book (De Inventione, De Oratore, Brutus, Orator). ${ }^{3}$ Quintilian's reference work is Institutio Oratoria, characterized by a systematic approach. Rhetoric can be first defined as the art of well-speaking, 'ars bene dicendi', according to Quintilian, ${ }^{4}$ which has been developed in Ancient Greece, closer ties to political institutions, in the context of the rise of city states (polis), linked with skilled public speaking and controversial debates. Actually, the definitions of this art are divergent, ${ }^{5}$ not least because each rhetorician had to set out his own point of view on rhetoric, before starting his career. ${ }^{6}$ Secondly, the importance of persuasion (pistis) through speech is claimed since the beginning of its history. Rhetoric has been largely defined as the power of persuasion (vis persuadendi). ${ }^{7}$ As the art of manipulation, it is associated with Sophistry, the art of the Sophists, specialized orators by profession, seeking to optimize the efficiency in communication. Plato accused them of confusing and sowing the seeds of doubt within the minds of citizen, drawing thus a distinction between philosophy and rhetoric. A third definition, according to Aristotle, is to be added to this brief survey: as the art of eloquence, rhetoric, deriving (paraphues) from dialectic but deprived of critical sense, ${ }^{8}$ consists in the development of arguments and discourses that aim to

\footnotetext{
1 On the first occurrences of the word 'rhêtorikê', see Pernot 2000, 38-40.

2 Cicero, De Inventione, 1. 2.

3 Guérin 2015, 175-190.

4 See Quintilian's definition of rhetoric in Institutio Oratoria, II, 15, 1.

5 Cassin 2015, 9-38; Dixsaut 2008.

6 See Desbordes 1996, "1. Situation de la rhétorique”.

7 See Quintilian, Institutio Oratoria, II, 5, on the several ancient definitions of rhetoric.

8 Aristotle, Rhetoric, I, 2, 1356a20-30.
} 
persuade the audience. ${ }^{9}$ Cicero and Quintilian also place a great deal of importance on its impact on the spectators. According to Cicero, when the speech is properly declaimed, the orator places the audience in a state of contentment, delight, or even affliction, just as he wanted them to feel and react. ${ }^{10}$

Homer is considered by Quintilian to be the father of rhetoric, since all the elements of this art are embedded in his epics. ${ }^{11}$ The poet satisfies the conditions of the well-achieved eloquence: he wins the audience's sympathy, he commands their attention and he makes listeners docile and capable of receiving what is being communicated. ${ }^{12}$ The Rhetorica ad Herennium had already developed a theory on the style registers. Moreover, Quintilian detects in Homer's verses the three suitable modes of discourse (genera dicendi), embodied by the characters of Menelaus, Nestor, and Ulysses. ${ }^{13}$

Many discursive and rhetorical techniques, technai, may have been discovered and implemented in speeches from Corax the Sicilian and his supposed student Tisias to Aristotle's work on rhetoric. The contribution of the Sophists to technê rhêtorikê is well established although there is little written evidence for it. Corax and Tisias were considered for a long time as the inventors of rhetoric's codification by Latin authors, although the art of eloquence is already codified and still closely linked to the art of persuasion in their days. ${ }^{14}$ These Sicilians put in writing an art and provided precepts, artem et praecepta Siculos Coracem et Tisiam conscripsisse, as Cicero puts it. ${ }^{15}$ Their names are related to the fall of tyrants and to the rise of democracy by Cicero in his Brutus, and they are artium scriptores antiquissimi, to use Quintilian's words in his Institutio Oratoria. ${ }^{16}$

Naturally, rhetoric is first an oral discipline. Once written, the speech is the tangible medium of a possible declamation. But most speeches are precisely drafted after their declamation. For instance, it is the case of Cicero's judicial and political speeches. His Pro Milone has been completely restructured after being performed. Writing may be a hindrance to improvisation, according to Alcidamas. ${ }^{17}$ But in most cases, writing is supposed to ensure the orator's good performance. ${ }^{18} \mathrm{~A}$ fine speaker knows that it is necessary to improvise and to be attentive to the present moment, in order to catch the appropriate one (kairos), when it flies by, as it is shown, for example, by Dionysius of Halicarnassus in The Arrangement of Words. ${ }^{19}$ Cicero emphasizes the need to adapt

\footnotetext{
9 On these three main definitions of rhetoric, see Meyer 2004.

10 Cicero, Brutus, 184-186.

11 Quintilian, Institutio Oratoria, X, 1, 46.

12 Quintilian, Institutio Oratoria, X, 1, 48.

13 Quintilian, Institutio Oratoria, II, 17, 5; XII, 10, 64.

14 See Desbordes 2009.

15 Cicero, Brutus, 46.

16 Quintilian, Institutio Oratoria, III, 1, 8.

17 Alcidamas, Against the Sophists, 15.

18 Cicero, De Oratore, I, 151; Orator, 150.

19 Dionysius of Halicarnassus, The Arrangement of Words, 12, 5.
} 
continuously to the various circumstances. ${ }^{20}$ Quintilian does not deny the importance of the ability to improvise ${ }^{21}$ which is required in the formation of the perfect orator. The Latin author outlines the need for students to complete practical exercises (progymnata) to reach the required level of an ease in public speaking and expressing (facilitas dicendi). ${ }^{22}$ Improvisation (extemporalis facilitas) is the state-of-the-art training, insofar as it clearly indicates the orator's adaptability to circumstances. ${ }^{23}$ In this way, rhetoric is fundamentally an art of time and space, the space of speech as it develops beyond words.

Rhetoric has been widely criticized because of its twofold purpose, since the art of eloquence aims to convince and persuade. Not only rational but also emotional means are implied, thus creating a gap between the speaker and his audience. Therefore, they are not on an equal footing (isêgoria). This element of irrationality in rhetoric has been severely criticized on some occasions. In this sense, Plato condemns in his dialogue Gorgias the appeal to the passions, expelling the commitment to Truth from speeches and the goals of the orator. This was also the case with Gorgias's psuchagogê, namely a way of leading souls, which is furthermore conceived by the Sophist in his Encomium of Helen as a spell put on the listeners' minds. ${ }^{24}$ Plato's distrust of the declamatory tricks of the Sophists is associated with his criticism of democracy, owing to the ignorance of the crowd bewitched by nice words, fascinated and unable to resist the liars. ${ }^{25}$ According to Plato, the orator has little regard for Truth and much prefers plausibility. Hence, he deceives his audience, which is a part of his psuchagogê. ${ }^{26}$ Nevertheless, Cicero and Quintilian consider this emotional power to be of central importance. As will be seen below, the part of discourse they call 'actio', namely 'delivery', precisely depends on the capacity to touch and move, to ensure public awareness and confidence, or to trigger an appropriate action.

Besides emotional skills, in order to create a persuasive argument, the orator draws on a precise category of signs, the 'sêmeia', which is the specific feature of what can be called the rhetorical 'demonstration'. As a matter of fact, the logic and the structure of the text run on rational interconnections between arguments and the search for evidence based on a classification of signs, given the particular nature and level of certainty their use implies. Whereas 'tekmêria' are irrefutable signs, the degree of uncertainty conveyed by signs such as 'sêmeia' and 'eikota' varies according to the circumstances of the case. A counterexample can always be provided against 'sêmeia', while 'eikota' are probative signs based on a preponderance of evidence,

20 Cicero, Orator, XXXVI, 123.

21 Quintilian, Institutio Oratoria, X, 7, 1, sqq.

22 See for instance Cicero, De Oratore, I, 32, 147-I, 35, 160.

23 See Celentano 2015, 191-212.

24 Gorgias, Encomium of Helen, 13.

25 Plato, Gorgias, passim.

26 Stroh 2009, 125-141. 
namely what can be called 'a reasonable certainty'. ${ }^{27}$ In the Prior Analytics, Aristotle takes the example of pallor and childbirth to show the discrepancy between an indubitable sign (tekmêrion) and an only probable sign (sêmeion). Pallor could be a sign of childbirth but it is not necessary the case. The causes of pallor are varied; the isolated sign of pallor, which is here a 'sêmeion', is not sufficient to prove childbirth. On the contrary, if a woman has milk, she has been certainly pregnant. ${ }^{28}$ While 'eikota' are mostly used in judicial discourses, 'sêmeia' are sought by rhetoricians.

The particularity of 'rhêtorikê' relies heavily on the use of this category of signs, within a specifically structured form of argumentation, which reflects the twofold nature of the art of eloquence. In this context, the strength of an argument is provided by a complex combination, insofar as it depends on the validity of the premises and the specific characteristics of the signs. In the logical section of his work, in the Organon, Aristotle studies the process of logical reasoning in these terms. The rhetorical syllogism, a deductive argument called 'enthymeme' (enthumêma) is a kind of rhetorical proof, a rhetorical deduction alongside 'paradeigma' and maxims. ${ }^{29}$ The audience trusts the orator on the basis of plausibility. Pistis is prior to the appeal to emotions. Enthymemes provide other ways of influencing the listeners. ${ }^{30}$ Unlike a well-established syllogism, enthymeme is a form of faulty reasoning, which could be truncated with an unstated premise, and based on signs instead of facts. Additionally, it is always rebuttable. Naturally, the notion of 'plausibility' allows room for interpretation. De facto, the reasoning based on enthymemes does not aim to properly demonstrate, since it includes an element of irrationality. ${ }^{31}$ This process touches on the imagination and emotions.

Building on this framework, besides logos, Aristotle describes the two other modes of persuasion to be found in rhetoric: on the one hand 'êthos' which covers the orator's character, namely the probity he could have shown in previous situations, his reputation, and his authority, and on the other hand 'pathos', which focuses on the appeal to the audience's emotions in order to ensure their openness, willingness, and support. This topic concerns the second book of Aristotle's Rhetoric. The orator's credibility and the confidence (pistis) he may inspire rely on his practical intelligence (phronêsis), virtuous character (aretê), and good will (eunoia).32 The orator should moreover display persuasive efforts to arouse the emotions of his audience. His own

27 Aristotle, Prior Analytics, II, 27.

28 Laurand 2005, 17-44.

29 On syllogisms and enthymemes, see: Aristotle, Prior Analytics, II, 27, 70b, 6-39, id. II, 2, Posterior Analytics I, 13, 78a28, Topics, On Sophistical Refutations, and also Rhetoric, I. I. 3; II, XX, 1.

30 Stroh 2009, 148, 152-153.

31 Aristotle, Rhetoric, I, 2, 1355b25-1356b.

32 Aristotle, Rhetoric, II, 1, 1378a6-8. 
character helps ${ }^{33}$ in this persuasive effort to communicate emotions. ${ }^{34}$ The theme of the good man (vir bonus dicendi peritus) ${ }^{35}$ is thus developed by Cicero and Quintilian, combined with the art of speaking well and echoing Aristotle's precepts about ' $e u$ legein'. They build on virtue as a condition of the well-performed speech and portray a perfect orator (orator perfectus), ${ }^{36}$ who resembles the Stoic wise man. Hence, the orator's personality, ${ }^{37}$ morality (honestas), reputation (auctoritas), greatness of soul (dignitas) play a central part in the discussion on passions, and consequently in the definitional process of rhetoric. ${ }^{38}$

As a matter of fact, Aristotle's Rhetoric begins with a study of passions such as anger, contempt, and hatred, carried out kata ta pathe,$^{39}$ and a delineation of characters, considering the notions of 'êthê', and 'hexis', namely someone's ethical behaviour and natural predisposition. The specific contribution of Aristotle sheds light on the central dimension of the anthropology of the passions, from which Latin authors draw inspiration, and lines up with Rhetoric and Problemata. The Rhetoric's typology and case-by-case approach is far more precise than the Nicomachean Ethics' list of the various states that the soul experiences when it is set in motions by passions. ${ }^{40}$ Aristotle creates an inventory of characters. Indeed, he delineates general categories whose scope is all of human nature. Besides, from a practical point of view, the orator needs to combine 'êthos' and 'pathos' if he wants to gain the support of the audience.

The connection Aristotle draws between 'êthos' and 'pathos' is also to be found in Latin theorization of public speaking. One finds in Cicero and Quintilian a survey of passions and characters, linked with the issue of discourse's efficiency, which is also involved in the moment of 'actio' described below. Their works show the maturity of Roman eloquence. Actually, they are at the junction of three main traditions: the issue of passions as developed by Aristotle, the body of knowledge of rhetoric, in particular since Corax and Tisias, and last but not least ancient physiognomics.

33 On 'êthopoiia', see Aristotle, Rhetoric, I, 1356a5-15.

34 See for instance Cicero, De Oratore, II, 189-191.

35 See for instance Cicero, De Oratore, I, 202, III, 52-55, Quintilian, Institutio Oratoria, II, 1, 25, 26.

36 On 'orator perfectus', see Cicero, De Oratore, and Orator, passim.

37 Cicero, Partitiones Oratoriae, 22, on the orator's character.

38 See for instance, Cicero, Partitiones Oratoriae, 90.

39 Aristotle, Rhetoric, II, 12.

40 Aristotle, Nicomachean Ethics, II, 4, 1105b25 sqq., for a definition of 'pathos'. The issue of passions in Aristotle's work is mainly to be found in Nicomachean Ethics, Rhetoric and Problemata. 


\section{Traditional physiognomics and rhetoric: Roots and focal points}

Physiognomics appears in antiquity well before the birth of the Graeco-Roman world. Its development goes hand in hand with the drafting of lexicographical lists in Mesopotamia. ${ }^{41}$ Physiognomics is established in omina and medical books, especially for the description of skin diseases and physical deformities. It has social consequences regarding the life of an individual, for instance life and death, family and offspring, social status, poverty or wealth, and social interactions like success at court. Physiognomics consists of a method of observation and provides a tool for medical decision-making and treatment. Lists of correspondences between objective physical characteristics and diseases are drawn up; the treatises contain inventories that cover the entire surface of the human body and are tied to precise interpretations. ${ }^{42}$ The organization of knowledge is conducted with elements from the multifaceted external reality of the individuals, and closer to a hermetic attempt to explain and understand the cosmos.

The transmission of the body of knowledge from the Babylonian to the GraecoRoman world is not easy to establish from the texts themselves. Nevertheless, the tradition of body depiction and deductions based on careful observation continues with the application and transformation of the physiognomic main topics, insofar as the emphasis on characters becomes a typical feature of Graeco-Roman physiognomics since the Peripatus. ${ }^{43}$

It is important to underline that the body of physiognomic texts is heterogeneous, protean, and scattered in time and space, first of all because physiognomics relies on entire sets of practices and ancient skills which were not just restricted to divination and medicine. Indeed, it even influences aesthetic purposes such as rhetoric, as at the time of Cicero and Quintilian. Besides its scientific developments, physiognomics includes an iconic dimension, which is revealed by the forms and patterns it acquires in later texts. Such an iconic dimension is particularly evident in the GraecoRoman context as well as in the literary devices, forms, and techniques occurring in Epic, Poetry, and Drama, not to mention its applications in the visual arts. ${ }^{44}$ Indeed, evidence of physiognomic descriptions can be found in Hesiod and even more in Homer's epics, ${ }^{45}$ in Simonides's poetry, in Aesop's poems, and in the great Greek

41 See inter alia Boisson, Kirtchuk, and Béjoint 1991, 261-315.

42 See inter alia Goltz 1974; Labat 1951.

43 On the anecdote about Socrates's character deciphered by a physiognomist of the Peripatus, see Foerster 1893, vol. 1, VIII sqq.

44 Elsner 2007, 203-224.

45 See inter alia Galhac 2007, 15-30; Joly 1962, 5-28. 
playwrights. ${ }^{46}$ As shown by E. C. Evans, ${ }^{47}$ physiognomics in the ancient world can be found not only in treatises, but also in philosophy and medicine, drama, rhetorical theory and practice, history and biography, epic, and other literary forms.

Actually, physiognomic reflections do in fact occur also outside the books explicitly devoted to it. Strictly speaking, its theorization is rather late in the Graeco-Roman world, particularly if we take into consideration the physiognomic annotations to be found in scientific and literary texts that existed long before Pseudo-Aristotle's Physiognomonica (ca 3rd cent. BC). ${ }^{48}$ This book is the first consistent theorization of physiognomics in the Greek world, which has come down to us. Pseudo-Aristotle's Physiognomonica remains influential up to the time of Cicero and Quintilian. The two other reference books of the Graeco-Roman world are later than the Physiognomonica, namely Polemo's treatise (2nd cent. AD) ${ }^{49}$ and the De Physiognomonia Liber of the Anonymous Latinus (4th cent. AD), ${ }^{50}$ which is therefore later than these two Roman orators.

In spite of the assumed heterogeneity of physiognomics, some main trends and patterns can be identified. Hence, the case by case approach remains the basis of this understanding of the natural world, and more specifically of human nature. For this reason, traditional physiognomics first relies on a conditional form, with a protasis beginning with the statement of a condition - 'if...', followed by the statement of the case - and an apodosis showing the outcome - 'then...', even though the logical connector is not always expressed. This syntactic structure, widespread in Babylonian and Hippocratic medical treatises, and also in ancient omen collections, corresponds to the statement of the underlying principle of the physiognomic causal inference. ${ }^{51}$ Although the logical structure is not identical in rhetoric, the key point is the empirical approach, and the case-by-case analysis that both Cicero and Quintilian provide in their discussions of the practise of their art, especially concerning the appeal to passions during oral argument in a court of law.

Moreover, thought processes based on analogy appear to be the best way to achieve those outcomes. ${ }^{52}$ Analogies draw interconnections between specific empirical characteristics on the one hand, and expertise referring actually to a broader knowledge on the other hand. Thus, traditional physiognomic statements rely on analogy and imply a rich semiology together with a specific reasoning, as shown by Aristotle in his Organon. Besides, physiognomic reasoning is a rhetorical syllogism, based on the use of 'sêmeia', marks of probability. The enthymeme obviously has

46 See Evans 1969, 1-100.

47 Ibid.

48 Degkwitz 1988.

49 Polemo, De Physiognomonia Liber, in Foerster 1893 and in Swain 2007.

50 Anonyme Latin, Traité de Physiognomonie, edited in André 1981.

51 It is the form taken by the first scientific treatises. See, inter alia, Glassner 1995.

52 See Talon 2004. 
something in common with the type of demonstration used in rhetoric: they actually share the same structure and they rely on the same combination of both rational and emotional elements, supported by only probable or even plausible arguments, as seen above. 'Sêmeia' and their ambiguity are at the very heart of the PseudoAristotle's explanations, so he does not exclude the possibility of demonstrating an interpretation through the accumulation of evidence..$^{53}$ Cicero and Quintilian as well have retained the lessons of 'sêmeia' and 'eikota' applied to their art. In addition, according to Pseudo-Aristotle, physiognomics is made up of variations in forms, colours, specific features on the face, hairiness, voice, flesh, and body parts ${ }^{54}-$ all aspects requiring the Roman orator's attention and interest, with a focus on gesture, gait, and behaviour. Hence, the observation of the body has been applied to the technique of eloquence.

Pseudo-Aristotle defines three physiognomic methods: ${ }^{55}$ firstly, the zoological method, which is based on the similarities and analogies drawn between human beings and animals - the vices and virtues associated with an animal are ascribed to an individual according to the physical similarities of this very animal; secondly, the ethnological method, which relies on an analogy between places and ethnicities, and the qualities allowed to the former are attributed to the latter; thirdly, the 'anatomopathognomic'56 method, which consists of the study of the characters, affections and states of body and soul, depending on passions. According to Pseudo-Aristotle, to practice physiognomics only on the basis of characters is a mistake, ${ }^{57}$ and the 'anatomo-pathognomic' method is insufficient to encompass and decipher the inner nature of human beings, precisely because of the heterogeneity of types, in spite of some observed and characteristic features. He takes the example of the brave man and the impudent man: their characteristic features are almost the same, while at the same time their mental states are significantly different. ${ }^{58}$ Moreover, the issue of temporality has to be taken into account, owing to the impermanence of some characteristics. A man who is sad by temperament may have a nice day, and yet at the end of it he may assume the features of a debonair person. ${ }^{59}$ Fleeting emotional states do not apply to well-defined physiognomics.

Thus, the attention that rhetoric paid to characters can be seen as a specific case of physiognomic practice, a kind of unfinished task, focusing on the 'anatomopathognomic' method. The similarity and difference between physiognomics and rhetoric are due to the way they link signs such as 'sêmeia' and their respective views

53 Ps.-Aristotle, Physiognomonica, 807a1.

54 Ps.-Aristotle, Physiognomonica, 806a20-34.

55 Ps.-Aristotle, Physiognomonica, 805a20 at 805b1.

56 I have chosen this specific term with reference to Elisabeth C. Evans's works on physiognomics.

57 Ps.-Aristotle, Physiognomonica, 805b1.

58 Ps.-Aristotle, Physiognomonica, 805b1.

59 Ps.-Aristotle, Physiognomonica, 805b5. 
on the passing of time. Physiognomics studies signs fixed through time, regardless of duration. Indeed, the physiognomist is not interested in the fugitive appearance of an emotion, but on the contrary he tries to identify and decipher the permanent traces that display a typical character on physical bodies.

In contrast, rhetoric expressly includes the dimension of temporality, namely fleeting moments. Indeed, Cicero and Quintilian, in their appeal to emotions, enhance the suddenness and the transitory nature of the passions and related signs that they elicit, in theorizing their art of speaking. They have taken note of the emotional brutality and intensity required in an oral argument. The appeal to pathos should not be confined to peroration but should appear at every moment of the talk (per totam causam), ${ }^{60}$ since pathos lies at the very heart of eloquence according to both Cicero and Quintilian. ${ }^{61}$ The convenient 'êthos' of the perfect orator is goodness and generosity. ${ }^{62}$ He knows the power of ephemeral passions (pathê) which he arouses as he likes. He praises the transitory emotions (adfecti), such as anger, hatred, greed for their violence, ${ }^{63}$ as efficient means to kindle the judges' pity or compassion. ${ }^{64}$

Furthermore, the famous pseudo-aristotelian catalogue of vices and virtues consists of special applications to human nature of a logic based on the analysis of conditionality. In this way, through the use of typologies, the study of individual specificities carves out a place inside the general Aristotelian framework, ${ }^{65}$ within which priority is absolutely given to general cases. ${ }^{66}$ Pseudo-Aristotle's Physiognomonica seeks to establish a characterology at the crossroads of the psychological and somatic. Twenty-two character types are presented in this book, ${ }^{67}$ with their specific features, outlining types such as the brave man, the cowardly man, the man with an innate goodness, the idiot, the brazen man, the choleric man, the ironic man, and so on. This methodological empiricism was already partly inspired by medicine and rhetoric. ${ }^{68}$ The changes in the states of the soul are correlated with bodily postures and attitudes, since body and soul affect each other, as Pseudo-Aristotle shows in his presentation of physiognomic practice. ${ }^{69}$ The Roman rhetoric of Cicero and Quintilian does not diverge from this. The rhetorical semiology of the passions deepens the theme of the

60 Quintilian, Institutio Oratoria, VI, 1, 51, VI, 1, 53, and VI, 2, 2.

61 Quintilian, Institutio Oratoria, VI, 2, 7.

62 Quintilian, Institutio Oratoria, VI, 2, 13.

63 On the difference of nature between mild emotions referring to êthê, a kind of continuous state (habitus) and violent ones, related to pathos, see Quintilian, Institutio Oratoria, VI, 2, 8, with an implicit reference to Cicero, De Fato, I, 1.

64 See, inter alia, Quintilian, Institutio Oratoria, VI, 10, VI, 1, 23.

65 Sassi 1988.

66 Ps.-Aristotle, Physiognomonica, 805b10-30.

67 Ps.-Aristotle, Physiognomonica, 807a31-808b10.

68 Cf. Laurand 2005, 191-207.

69 Ps.-Aristotle, Physiognomonica, 805a1-807a30. 
movements of the soul and their bodily transcription, because emotions are correlated with moral attitudes and characters for the benefit of the oral argument.

Pseudo-Aristotle's catalogue of vices and virtues in the Physiognomonica, initially an inventory of signs which associates physical characteristics with lists of moral specifications, thus becomes a focal point for physiognomics and rhetoric. Physiognomics is in fact a starting point to study the lasting passions tied to the basic temperament and even to the transitory emotions aroused by rhetoric. Not only the general category delineated by the physiognomic type is worthy of interest for the Roman rhetoricians. They develop an interest in personal characterization through emotions, which is supported by the attention paid to the non-permanent signs. This is a kind of variation around the ambiguity of the 'sêmeion', the typically physiognomic sign, sometimes questionable, doubtful, shady (anceps and dubius), which paves the way for a psychological approach to human nature, a concern typically echoed in discussions of Roman eloquence. Indeed, this trend increasingly sharpens in the Graeco-Roman world, with an increasingly moral emphasis. Morality associated with psychology is a commonplace of physiognomics and rhetoric.

Physiognomic approaches deal with general categories. Regarding the 'anatomopathognomic' method, types provided by the passions mainly delimit them. The issue of morality (êthos) is approached in association with the crucial role of characteristic signs, and by extension, with the depiction of behaviour. Physiognomics links 'êthos' with 'pathos' in a discourse structured by the systematic analysis of analogical correspondences. Its specific 'logos' is that of probability and plausibility, since it relies on 'sêmeia' and 'eikota'. ${ }^{70}$ In rhetoric, 'êthos' (how the character and the speaker affect the audience), 'pathos' (the way emotions play a role in arguments and in the performed speech), and logos (the structure of the argument, relying on the use of logic) are closely linked together. ${ }^{71}$ The logos of rhetoric is also that of probability and plausibility, but its purpose focuses on mutable and labile signs, and even micromovements, instead of the ideally physiognomic fixed and permanent signs. In some ways, 'êthos', 'pathos', and 'logos' intertwine closely in the networks of physiognomics and rhetoric.

I intend to shed light now on the precise intersection of 'êthos' and 'pathos' in the eloquent body (quasi sermo corporis) ${ }^{72}$ as defined by rhetoric, particularly in the delivery (actio). As we will see, such intersection is most evident in Cicero's and Quintilian's rhetorical transformation and application of traditional physiognomics.

70 On the use of signs in Cicero's and Quintilian's books, related to 'technê rhêtorikề', see Crapis 1988, 175-197.

71 On 'êthos' and 'pathos' in rhetoric, see for instance Cicero, Orator, XXXVII-XXXVIII, 128-133.

72 Cicero, De Oratore, III, 59, 222. 


\section{The vivid language of 'quasi sermo corporis' and 'actio': An applied and transformed physiognomics}

Both physiognomists and rhetoricians take careful account of the body but from slightly different points of view, though there are points of convergence. Physiognomics can be understood as a technique which enables the deciphering of the body. The grids of physiognomic correspondence and the prospect of reading signs open up the possibility that the body can be made eloquent. This can be easily turned to the idea that the eloquent body is a natural object to invest in for a rhetoric in the 'anatomo-pathognomic' modality, i.e. for a rhetoric understood as the proper art of public speaking, which includes gesture and behaviour, and recurs to a vivid language. ${ }^{73}$ In this context, the vivid language is like a 'sermo corporis' and 'actio' appears thus as an applied and transformed physiognomics.

Besides the choice of proofs (inventio), several parts of the discourse aim at persuading the audience - 'dispositio', namely the arrangement of the arguments in the discourse; 'elocutio', the choice of the words and appropriate style; and 'actio', which completes the process, namely the speech's 'delivery' moment (agere and pronuntiare). 'Actio' appears already in Greek rhetoric, namely in Aristotle, who uses the term 'hupokrisis' to indicate the orator's use of voice. ${ }^{74}$ The term 'hupokrisis' brings this part of speech closer to the art of actors, and of their supposed excesses, since Aristotle accuses them of enhancing the effects of pathos, just as the Sophists he criticises for the same reason. Aristotle's remarks on delivery are mostly subordinated to accounts of style. In the Greek world, Theophrastus presumably lays the initial foundation of the rhetorical art of 'hupokrisis'. Indeed, one of his books is specifically devoted to the delivery of speech, as the title (On Delivery) shows. In this unfortunately lost book, Theophrastus deals with the pitch of voice as well as the bodily movement. ${ }^{75} \mathrm{He}$ also pays great attention to physiognomic ideas in his Characters, where he displays a series of portraits which resemble the physiognomic depictions of Pseudo-Aristotle's Physiognomica.$^{76}$ Some indications on hupokrisis can also be found in Athenaeus (2nd cent. BC).

Rhetoric arrives in Rome at the beginning of the second century before Christ. The Greek masters were read later on: their art of eloquence is widespread at the beginning of the first century before Christ. The Rhetoric for Herennius (86-83 BC), the earliest surviving Roman theorization of the five parts of rhetoric, namely invention, arrangement, style, delivery, memory (inventio, dispositio, elocutio, actio, memoria),

73 Rhetorical theory also uses terms employed for physical description, found also in physiognomics. See Evans 1969, 40; Misener 1924, 97-123.

74 Aristotle, Rhetoric, III, 1403b-1404a.

75 See fr. 712, Theophrastus of Eresus in Fortenbaugh, Huby, Sharples and Gutas 1993.

76 See Evans 1969, 39. 
long attributed to Cicero but of unknown authorship, is written in the context of political change, after the Punic wars, and in the face of strong political opposition. ${ }^{77}$ This book provides the system of classical rhetoric. It is addressed to an upper-class Roman, who didn't have the chance to read Greek authors, in order to fill in this gap. Descriptive on the whole, it deals with general principles, combining Aristotle's theory with Hellenistic devices and Roman realia. The discussions of delivery stem from a kind of historical synthesis. A large section of Book III investigates the several aspects of actio. $^{78}$

In the Rhetoric for Herennius, Cicero and Quintilian's works are at the heart of the Roman rhetorical interpretation of the traditional physiognomic body of knowledge. In the world of written rhetoric, delivery and memory receive less attention than the other parts of speech, and they are neglected for the benefit of actors who had taken up the subject. ${ }^{79}$ Nevertheless, Cicero, and Quintilian following him, claims that delivery and memory are the most important aspects of speech in several works, including De oratore, Brutus, and Orator. These two aspects of speech are of core importance in Roman rhetoric. According to Quintilian, Demosthenes puts the delivery in the first, the second, and even the third positions among the orator's skills and values. ${ }^{80}$ Cicero considers 'pronuntiatio' to be an essential part of the art of moving the audience (movere). ${ }^{81}$

Moreover, 'actio' includes reflections on non-verbal communication. In delivery, the shaping of speeches shows the difficulty of embodiment and emotional manipulation. Voice quality, including tones, breath, volume, rhythm, namely voice as a vocal non-verbal behaviour, facial expression (vultus) and gesture (gestus) as parts of body language, are discussed, in relation with each occasion, to suit the various subjects of oratory and moods. ${ }^{82}$ Cicero and Quintilian adopt a case-by-case method in accordance with general principles, within the framework of 'mediocritas aurea', the ancient topos of moderation (moderatio). This range of considerations is associated with hypotheses on the origin of language, regarding the supposed universality of gesture and facial expression, ${ }^{83}$ since this form of communication relies on a community of language. ${ }^{84}$ Thus, rhetoric has a shared universal goal.

The representation or the imitation of passions is the main issue at stake, which underscores the annotations about the three ingredients of a well-performed actio, as

77 Kennedy 1994, 121-127.

78 Rhetorica ad Herennium, 3, 19-23 (delivery), 3, 24-25, (delivery: voice), 3, 26-27 (delivery: gesture).

79 See inter alia Cicero, De Oratore, III, 57, 214.

80 Cicero, De Oratore, III, 56, 213; Quintilian, Institutio Oratoria, XI, 3, 7.

81 Cicero, Orator, 56; Brutus, 142, and Quintilian, Institutio Oratoria, XI, 3, 2-7.

82 On the appropriate delivery, see for instance Quintilian, Institutio Oratoria, XI, 3, $63-65$.

83 On this particular point, see Fögen 2009, 15-43.

84 Cicero, De Oratore, III, 59, 223. 
Cicero claims in his introduction to 'actio', ${ }^{85}$ which is equivalent to style in terms of body posture. ${ }^{86}$ 'Elocutio' and 'actio' are complementary, but 'actio' may enhance or ruin 'elocutio' if not correctly performed. ${ }^{87}$ On the distinction between 'actio' and 'pronuntiatio', insofar as these terms are often confused, Quintilian remarks that 'pronuntiatio' is more suitable for voice than gesture. ${ }^{88}$ Moreover, in the Orator Cicero does not employ the term 'pronuntiatio'. 'Actio' is thus divided into two parts: voice (vox) on the one hand and the movement (motus) of the body expressing the movements of soul (moti animi) on the other hand. Indeed, Cicero focuses on voice, gesture, and physiognomy, because finally all depends on physiognomy: "Sed in ore sunt omnia" ${ }^{99}$ The soul-body correspondence is the precondition for the success of the process, since it enables the performance to be achieved from both a conceptual and an empirical point of view. ${ }^{90}$

Thus, in his De Oratore, Cicero deals with the several pitches of voice (Book III, 57-58, 214-219), gesture (gestus) (Book III, 59, 220), the physio-pathognomic aspect of face (vultus) (Book III, 59, 221-223), and the voice (Book III, 60-61, 224-227). In his Orator (XVII-XVIII, 55-60) he deals with voice and gesture too. He examines the volume, flexibility, stability, and velocity of voice, the tones (inflexo, acuto, gravi) and modulations, ${ }^{91}$ the speech rate appropriate to express vehemence, anger, fear, and other strong feelings. Cicero links tones to musical chords and delivery to emotion. Moreover, the inflections of voice are compared with the colours on the artist's pallet for their capacity to render the subtleties and hues of emotions. ${ }^{92}$ The notion of colour contributes to bringing harmony to the discourse. It is not only one sign among others. Colour has a concrete and a critical sense, since the art of eloquence is backed by a plastic and graphic imagination. It is as if the body of speech is itself coloured, as 'color' indicates the health of an individual. ${ }^{93}$

85 Cicero, De Oratore, III, 56, 213-214; on the 'movere', see De Oratore, III, 45-50, 185-204, and on the means to arouse passions, De Oratore, III, 51-53, 204-216.

86 Cicero, Orator, I, 17, 55, “est enim actio quasi corporis quaedam eloquentia”, and De Oratore, III, 59, 222 “quasi sermo corporis”.

87 Cicero, De Oratore, III, 56, 13; Orator, XVII, 56.

88 Quintilian, Institutio Oratoria, XI, 3, 1.

89 Cicero, De Oratore, III, 59, 221. See also Cicero, De Oratore, III, 57, 216, "Each movement of the soul is designed to be mirrored by the physiognomy, the sound of voice, and gesture; and the whole body of man, his physiognomy, the pitches and tones of his voice sound like the strings of the lyre, according to the movement of the soul, which sets them in motion" (My translation); "Omnis enim motus animi suum quendam a natura habet uultum et sonum et gestum; corpusque totum hominis et eius omnis vultus omnesque uoces, ut nerui in fidibus, ita sonant, ut a motu animi quoque sunt pulsae". 90 Cicero, De Oratore, III, 59, 221.

91 Cicero, Orator, XVIII, 58.

92 Cicero, De Oratore, III, 57, 217.

93 On this particular point, see Lévy 2006, 185-199. 
Gestures should accompany tones. In comparison with actors, excess in gesture should be avoided..$^{94}$ Cicero takes the art of fencing and the paelestra as his models instead..$^{95}$ The orator tries to be expressive without grinning. ${ }^{96}$ The face is considered as a reflection of the soul, and the eyes are the windows to the soul, ${ }^{97}$ because eyes express the movements of soul. ${ }^{98}$ The eyes are paramount in the art of delivery. The micro-movements are of importance too and they should be well balanced. The orator should pay attention to standing upright, not too straight, to moving rarely and with moderation, to keeping his chest straight. The observation of the movements of the neck, fingers, phalanges, and arms shows his acute sense of decorum and codification of manliness. ${ }^{99}$ The variations in physiognomy support achievement of the expression of the soul movements, with regard to Atticism and its ideal of sobriety. ${ }^{100}$ The moral attitude embodied by the orator is suitable to ethics (êthos), namely "what is appropriate to temperaments, morals, and the conduct of life", ${ }^{101}$ while the expression of the passions is bent on 'pathos', insofar as the pathetic "troubles and excites the hearts". 102

Quintilian develops his theorization and normative recommendations in line with Cicero's body of references. His division of 'actio' in voice and gesture, with an emphasis on physiognomy, follows and extends his predecessor's theorization. His work contains long descriptions devoted to the bodily conditions of a fine delivery. 'Actio' should charm eyes and ears. ${ }^{103}$ However, he deepens this latter field of research to open broadly rhetoric to its ekphrastic dimension. The Institutio Oratoria's Books VI (especially sections 1 and 2) and XI (especially section 3) contain a lot of information on the application and transformation of traditional physiognomics for a rhetorical purpose. Besides, the expression of diversity ${ }^{104}$ is correlated with the general categories of the Aristotelian framework. Thus, the pathognomic pattern developed by Roman rhetoric covers the scope of human nature from a still physiognomic point of view. The physio-pathognomic depictions are included in a set of countable species. ${ }^{105}$

94 Cicero, De Oratore, III, 59, 220.

95 Ibid.

96 Cicero, De Oratore, III, 59, 222.

97 Cicero, Orator, XVIII, 60, “Nam ut imago est animi vultus, sic indices oculi”.

98 See for instance Cicero, De Oratore, III, 221, and De Legibus, 27.

99 Cicero, Orator, XVIII, 59. On 'manliness' in speech, see Gleason 1995.

100 Cicero, Orator, XXV, 86.

101 Cicero, Orator, XXXVII, 128, “ad naturas et ad mores et ad omnem vitae consuetudinem accomandatum".

102 Ibid., "perturbantur animi et concitantur".

103 Quintilian, Institutio Oratoria, XI, 3, 13.

104 Quintilian, Institutio Oratoria, XI, 3, 17.

105 Quintilian, Institutio Oratoria, XI, 3, 18. 
Quintilian also looks into the rhetorical treatment of voice, ${ }^{106}$ quantitatively and qualitatively assessed, ${ }^{107}$ including volume, ${ }^{108}$ pitch and rhythm, all important to whether a speech is successful or not. ${ }^{109}$ The manipulations of voice, breath, ${ }^{110}$ and rhythm define the figure of voice, which is correlated with the movement of the body, because of the body-soul connection. An "urbane pronunciation" is required. ${ }^{111}$ Glance is also part of the social codification of the face-to-face implied by physiognomics in his rhetorical application. ${ }^{112}$ In the second century, Polemo, also an orator by profession, will dramatically highlight the physiognomics of the eyes, ${ }^{113}$ and its social consequences.

The genuine originality of Quintilian's transformation of traditional physiognomics relies on his explanations of micro-movements, nurtured by characters and the flow of passions, and as a natural extension of gesture and facial expression. He notably describes the micro-movements of the hands, eyelids and cheeks, ${ }^{114}$ nostrils and lips, ${ }^{115}$ fingers and so on. He also discusses nods, ${ }^{116}$ facial mimicry, ${ }^{117}$ the mobility of eyebrows, ${ }^{118}$ and the like. Facial expressions are compared with the characters of comedy. ${ }^{119}$ The physiognomic depiction of moral characters and attitudes is to be found in such explanations and descriptions. Moreover, what is suitable regarding style and decent behaviour in society is clearly depicted, not least because lawyers needed to remedy their bad habits.

Thus, Quintilian shapes a mental universe of micro-correspondences and significations, a grey zone between the physiognomic permanence and the mutability of bodily passions. In the same vein, in Quintilian's rhetoric colours, such as blushes, are associated not only to physiology but also to the value system of decency and convenience, ${ }^{120}$ within a broader moral framework, as mentioned above. The vivid language of eloquence covers and illustrates the ambiguities of the ekphrastic body depicted in this way. Eloquence thus provides the rhetorical portrayal of human nature. These last particular aspects of Quintilian's rhetoric represent the highest level of the transformation and application of traditional physignonomics into rhetoric.

106 Quintilian, Institutio Oratoria, XI, 3, 14-45.

107 Quintilian, Institutio Oratoria, XI, 3, 14.

108 Quintilian, Institutio Oratoria, XI, 3, 15.

109 On how to make an effective use of voice: Quintilian, Institutio Oratoria, XI, 2, 65-68.

110 Quintilian, Institutio Oratoria, XI, 3, 16.

111 On the notion of urbanitas, see Book VI, 2.

112 On the concept of 'face' and social interaction, see Swain 2007, 141.

113 See Cairns 2005, 123-155.

114 Quintilian, Institutio Oratoria, XI, 3, 77.

115 Quintilian, Institutio Oratoria, XI, 3, 80-81.

116 Quintilian, Institutio Oratoria, XI, 3, 66.

117 On this topic, see Bühler 1933, 227-235.

118 Quintilian, Institutio Oratoria, XI, 3, 78, 79.

119 Quintilian, Institutio Oratoria, XI, 3, 75-76, 112.

120 Lévy 2006, 198. 
The Second Sophistic will also transform and apply physiognomics with a genuine ekphrastic purpose, as for instance in Philostratus's Imagines.

\section{Conclusion}

The reasons for investing in the field of rhetoric are varied, and philosophers, politicians, orators, and writers have contributed to the development and influence of this art, combining stylistic skills, bodily language, and theatrical facilities. At the time of Cicero and Quintilian, a new light was cast on rhetoric by physiognomics. Actually, physiognomics, based on analogies, conditionality, and probabilities, assesses the body-soul connection, and thus links together the quality of characters and physical attributes emphasizing permanent signs. Both rhetoric and physiognomics focus on the human body, rely on the category of 'sêmeion' - a probable and plausible sign not an irrefutable proof, and are based on a careful observation of passions and temperaments. They associate 'logos', 'êthos' and 'pathos', as the 'anatomo-pathognomic' method shows. Hence, the grey zone of blended rationality and emotion is outlined, taking into account the ethical characterization of human nature, revealed by movements of soul and bodily significant signs, to be deciphered and interpreted. This triple articulation of principles detailed a mental map of human nature viewed from the central dimension of the anthropology of passions that both physiognomics and rhetoric delineate in their own way. Physiognomics provides rhetoric with specific strategic tools to optimize the efficiency of its theories on the eloquence of the body. The case-by-case approach enriches the understanding of the multifaceted character of human nature. In this way, rhetoric applies, develops, and transforms the traditional physiognomic material into a vivid bodily language to be performed, according to social codifications of convenience and ideals of moderation. The well-performed speech and portrayal of the perfect orator find their place in the framework of body depiction. Thus, the use of physiognomics in speech leads both Cicero and Quintilian to the study of gesture, voice and physiognomy, especially for the purpose of delivery. Delivery is a key point for the characterization of this grey-zone between physiognomics and rhetoric, between physiognomic permanence and pathognomic mutability. Micromovements and evanescent bodily colours outline the tendency, strongly emphasised by Quintilian, toward an ekphrastic transformation of physiognomics. The rhetorical aesthetics of Cicero and Quintilian is caught in the middle: it is not completely determined by traditional physiognomic methods but it is rooted in it. For these orators, rhetoric remains an art of public speaking, and for this reason, the hermeneutic dimension of physiognomics is highlighted through word and dialogue inscribed in the body. But in another way, the concrete intermediary state in which they place bodies is characteristic of their rhetoric. In this sense, the rhetoric of Cicero and Quintilian paves the way to the properly iconistic and ekphrastic transformation of ancient physiognomics. 


\section{Bibliography}

\section{Primary sources}

Aeschylus and Sophocles: Grosjean, J. \& Dreyfus, R. (eds.) 1967. Tragiques Grecs, vol. 2. Paris.

Alcidamas: Muir, J. V. (ed.) 2001. Against the Sophists. In: The Works and Fragments of Alcidamas.

London.

Anonymus Latinus: André, J. (ed.) 1981. De Physiognomonia Liber. Traité de Physiognomonie. Paris.

Aristotle: Rackham, H. (ed.) 1934. Nichomachean Ethics. Cambridge, MA.

Aristotle: Forster, E. S., \& Furley, D. J. (eds.) 1978. On Sophistical Refutations. Cambridge, MA.

Aristotle: Forster, E. S., \& Tredennick, H. (eds.) 1966. Posterior Analytics; Topica. Cambridge, MA.

Aristotle: Mayhew, R. (ed.) 2011. Problems (1-19, and 20-38). Cambridge, MA.

Aristotle: Freese, J. H. (ed.) 1982. The Art of Rhetoric. Cambridge, MA. And in Dufour, M., \& Wartelle, A. (eds.) 1932-1973. Rhétorique. Paris.

Aristotle: Cook, H. P., \& Tredennick, H. (eds.) 1983. The Categories on Interpretation; Prior Analytics. Cambridge, MA.

Cicero: Hendrickson, G. L., \& Hubbell, H. M. (eds.) 1971. Brutus; Orator. Cambridge, MA. And in Martha, J. (ed.) 1960. Brutus. Paris. And in Yon, A. (ed.) 2008. L'orateur. Paris.

Cicero: Rackham, H. (ed.) 1982. De Oratore: Book III; De Fato; Paradoxa Stoicorum; De Partitione Oratoria. Cambridge, MA. And in Courbaud, E., \& Bornecque, H. (eds.) 2010. De l'orateur: Livre III. Paris.

Cicero: Keyes, C. W. (ed.) 1970. De Re Publica; De Legibus. Cambridge, MA.

Dionysius of Halicarnassus: Usener, H. \& Radermacher, L. (eds.) 1899. The Arrangement of Words. Leipzig. Gorgias: MacDowell, D. M. (ed.) 1982. Encomium of Helen. Bristol.

Euripides: Delcourt, M. (ed.) 1962. Tragiques Grecs, vol. 1. Paris.

Hesiod: Most, G. W. (ed.) 2006. Theogony; Works and Days; Testimonia. London.

Homer: Murray, A. T. (ed.) 1999. Iliad. Revised by William F. Wyatt for the 2nd edition. Cambridge, MA.

Homer: Murray, A. T. (ed.) 1975-1976. The Odyssey, in Two Volumes. Cambridge, MA.

Philostratus: Fairbanks, A. (ed.) 1979. Imagines. Cambridge, MA.

Plato: Lamb, W. R. M. (ed.) 1975. Lysis; Symposium; Gorgias. Cambridge, MA.

Polemo: Foerster, R. (ed.) 1893. De Physiognomonia Liber. In Scriptores Physiognomici Graecis et Latini. Leipzig. And in Swain, S. 2007. Seeing the Face, Seeing the Soul: Polemon's Physiognomy from Classical Antiquity to Medieval Islam. Oxford.

Pseudo-Aristotle: Degkwitz, A. (ed.) 1988. Physiognomonica. In Die Pseudoaristotelischen 'Physiognomonica': Traktat A. Übersetzung und Kommentar. Heidelberg.

Quintilian: Butler, H. E. (ed.) 1993-1996. Institutio Oratoria; Books I-III; IV-VI; VII-IX; X-XII. Cambridge, MA. And in Cousin, J. (ed.) 1975-1980. Institution oratoire; Livres I, II-III, IV-V, VI-VII, VIII-IX, X-XI, XII. Paris.

Rhetorica ad Herennium: Achard, G. (ed.) 1989. Rhétorique à Herennius. Paris.

Simonides: Campbell, D. A. (ed.) 1990-1993. On Women. In Greek Lyric. Cambridge.

Theophrastus: Fortenbaugh, W. W., Huby, P. M., Sharples, R. W., and Gutas, D. (eds.) 1993. On Delivery; Characters. In Theophrastus of Eresus: Sources for His Life, Writings, Thought and Influence. Leiden.

\section{Secondary literature}

Boisson, C., Kirtchuk, P., and Béjoint, H. 1991. “Aux origines de la lexicographie: les premiers dictionnaires monolingues et -bilingues". In: International Journal of Lexicography 4.4, 261-315. 
Bühler, K. 1933. “Der Rhetorische Gebrauch von Mimik und Gesten nach Quintilian”. In: Appendix to Ausdruckstheorie: das System an der Geschichte aufgezeigt. Jena, 227-235.

Cairns, D. L. 2005. "Bullish Looks and Sidelong Glances: Social Interaction and the Eyes in Ancient Greek Culture”. In: D. L. Cairns (ed.), Body Language in the Greek and Roman Worlds. Swansea, 123-155.

Cassin, B. 2015. “Esquisse de typologie des définitions de la rhétorique de Platon à Ælius Aristide”. In: B. Cassin (ed.), La rhétorique au miroir de la philosophie. Paris, 9-38.

Celentano, M. S. 2015. “La rhétorique de l’improvisation chez Quintilien, Institutio Oratoria, 10, 7”. In: B. Cassin (ed.), La rhétorique au miroir de la philosophie. Paris, 191-212.

Crapis, C. 1988. "Théorie des indices dans la rhétorique latine”. In: Versus 50/51: 175-197.

Desbordes, F. 1996. La rhétorique antique. L'art de persuader. Paris.

Dixsaut, M. 2008. “La rhétorique, une définition impossible?”. In: F. Aronadio et al. (eds.), Anthropine sophia? Studi di filologia e storiografia filosofica in memoria di Gabriele Giannantoni. Naples, 79-103.

Elsner, J. 2007. “Physiognomics: Art and Text”. In: S. Swain (ed.), Seeing the Face, Seeing the Soul: Polemon's Physiognomy from Classical Antiquity to Medieval Islam. Oxford, 203-224.

Evans, E. C. 1969. "Physiognomics in the Ancient world". In: Transactions of the American Philosophical Society 59(5): 1-100.

Fögen, T. 2009. “Sermo corporis: Ancient Reflections on Gestus, Vultus and Vox". In: T. Fögen \& M. M. Lee (eds.), Bodies and Boundaries in Graeco-Roman Antiquity. Berlin, 15-43.

Galhac, S. 2007. “Ulysse aux mille métamorphoses?”. In: F. Prost \& J. Wilgaux (eds.), Penser et représenter le corps dans l'antiquité. Rennes, 15-30.

Glassner, J.-J. 1995. “The Use of Knowledge in Ancient Mesopotamia”. In: J. M. Sasson (ed.), Civilizations of the Ancient Near East. New York, 1815-1823.

Gleason, M. W. 1995. Making Men: Sophists and Self-Presentation in Ancient Rome. Princeton.

Goltz, D. 1974. Studien zur Altorientalischen und Griechischen Heilkunde, Therapie Arzneibereitung - Rezeptstruktur. Wiesbaden.

Guérin, C. 2015. "Définir l'ars dicendi: enjeux et méthode de la réflexion cicéronienne dans le De Oratore”. In B. Cassin (ed.), La rhétorique au miroir de la philosophie. B. Cassin. Paris, 175-190.

Kennedy, G. A. 1994. A New History of Classical Rhetoric. Princeton.

Joly, R. 1962. “La charactérologie antique jusqu’à Aristote”. In: Revue Belge de Philologie et d'Histoire 40(1): 5-28.

Labat, R. 1951. Traité akkadien de diagnostics et pronostics médicaux. Paris.

Laurand, V. 2007. "Du morcellement à la totalité du corps: lecture et interprétation des signes physiognomoniques chez le Pseudo-Aristote et chez les Stoïciens”. In: F. Prost \& J. Wilgaux (eds.), Penser et représenter le corps dans l'antiquité. Rennes, 191-207.

Laurand, Valéry. 2005. “Les hésitations méthodologiques du Pseudo-Aristote”. In: C. Bouton, V. Laurand \& L. Raïd (eds.), La physiognomonie, problèmes philosophiques d'une pseudoscience. Paris, 17-44.

Lévy, C. 2006. “La notion de color dans la rhétorique latine”. In: A. Rouveret, S. Dubel and V. Naas, (eds.) Couleurs et matières dans l'antiquité: textes, techniques et pratiques. Paris, 185-199.

Meyer, M. 2004. La rhétorique. Paris.

Misener, G. 1924. “Iconistic Portraits”. In: Classical Philology 19(2), 97-123.

Pernot, L. 2000. La rhétorique dans l'antiquité. Paris.

Sassi, M. M. 1988. La scienza dell'uomo nella Grecia antica. Turin.

Stroh, W. 2009. Die Macht der Rede: eine Kleine Geschichte der Rhetorik im Alten Griechenland und Rom. Berlin.

Talon, P. 2004. “La transmission du savoir en Mésopotamie ancienne”. In: Civilisations 52(1), 25-33. 
